\title{
KEADAAN SANITASI RUMAH PENDERITA INFEKSI SALURAN PERNAPASAN AKUT PADA BALITA DI WILAYAH KERJA UPTD PUSKESMAS I DINAS KESEHATAN KECAMATAN DENPASAR SELATAN TAHUN 2020
}

\author{
Masid Zuniken Oktarini ${ }^{1}$, I Wayan Suarta Asmara ${ }^{2}$
}

\begin{abstract}
The purpose of this study was to determine the sanitation condition of Acute Respiratory Infections sufferers in under-five children in the work area of the public health center one regional technical implemention unit of the South Denpasar District Health Office. This type of research is descriptive by observation, interview and measurement of the physical quality of the environment. From this study the results obtained $100 \%$ of the conditions of the floor of the room meet the requirements, $46.2 \%$ of the houses of patients with natural ventilation meet the requirements that is $10 \%$ of the floor area and $53.8 \%$ of the ventilation of houses do not meet the requirements, $46.2 \%$ of the houses with lighting meet the requirements and 53.8 did not meet the requirements, $44.2 \%$ of the houses with room temperature that did not meet the requirements and $55.8 \%$ of the room temperature that did not meet the requirements, $42.3 \%$ of the houses with humidity that were eligible and $57.7 \%$ of the houses with no humidity. eligible, $48.1 \%$ of houses meet the density of sleeping space and $51.9 \%$ of houses do not meet the density of occupancy.
\end{abstract}

Keywords: Home Sanitation, Acute Respiratory Infections, Toddler

\section{PENDAHULUAN}

Infeksi saluran pernapasan akut (ISPA) adalah penyakit infeksi akut yang menyerang salah satu bagian / lebih dari saluran napas mulai hidung alveoli termasuk adneksanya (sinus rongga telinga tengah pleura) 1. Berdasarkan laporan Riset Kesehatan Dasar (Riskesdas) tahun 2013 ISPA disebabkan oleh virus / bakteri yang diawali dengan panas dengan disertai salah satu atau lebih gejala (tenggorokan sakit, nyeri telan, pilek, batuk kering atau berdahak) ${ }^{2}$.

Periode prevalensi ISPA nasional berdasarkan data Riset Kesehatan Dasar (Riskesdas) 2013, mencapai 25\% dengan 25,8\% didominasi oleh kasus ISPA pada balita (1-4 tahun). Penyakit ISPA disebabkan oleh bakteri atau virus yang masuk kesaluran napas dan menimbulkan reaksi inflamasi. Virus yang sering menyebabkan ISPA pada balita yaitu 
influenza-A,adenovirus, Parainfluenza virus. ISPA termasuk golongan Air Borne Disease yang penularan penyakitnya melalui udara. Patogen yang masuk dan menginfeksi saluran pernapasan dan menyebabkan inflamasi ${ }^{3}$.

Menurut WHO tahun 2013 di dunia angka kematian anak akibat pneumonia atau infeksi saluran pernapasan akut yang mempengaruhi paru-paru dinyatakan menjadi penyebab kematian yaitu sekitar 1,2 juta kematian anak setiap tahun. Dapat dikatakan setiap jam ada 230 anak di dunia yang meninggal karena pneumonia ${ }^{4}$.

Menurut Dinkes Provinsi Bali (2017), cakupan penemuan kasus pneumonia pada balita tahun 2017 sebesar 14,3. Kondisi ini menunjukkan status kesehatan balita yang semakin membaik sehingga kasus pneumonia mulai menurun. Menurut Kabupaten/Kota Provinsi Bali Tahun 2017 tingkat kejadian penderita ISPA di Kabupaten Gianyar sebesar 28,8\%, Kabupaten Karangasem 24,1\%, Kabupaten Klungkung 22,5\%, Kabupaten Jembrana 17,4\%, Kota Denpasar 15,9\%, Provinsi 14,3\%, Kabupaten Tabanan 13,3\%,
Kabupaten Buleleng 10,8\% dan Kabupaten Badung 4,1\%, Kabupaten Bangli 2,6\% 5 .

Tujuan penelitian ini untuk mengetahui keadaan sanitasi rumah penderita ISPA pada balita di wilayah kerja UPTD Puskesmas I Dinas Kesehatan Kecamatan Denpasar Selatan tahun 2020.

\section{METODE PENELITIAN}

Jenis penelitian yang digunakan dalam penelitian ini adalah deskriptif. Penelitian deskriptif bertujuan untuk melihat gambaran fenomena (termasuk kesehatan) yang terjadi di dalam suatu populasi ${ }^{6}$. Pengambilan data dilakukan dengan cara observasi, wawancara dan pengukuran kualitas fisik lingkungan dimana penulis ingin mendapatkan gambaran mengenai keadaan sanitasi rumah penderita ISPA pada balita yang meliputi luas ventilasi, keadaan lantai, pencahayaan, suhu ruang, kelembaban dan kepadatan hunian di Wilayah Kerja UPTD Puskesmas I Dinas Kesehatan Kecamatan Denpasar Selatan.

Populasi dalam penelitian ini adalah rumah KK penderita ISPA yang tercatat pada buku registrasi di UPTD Puskesmas I 
Dinas Kesehatan Kecamatan Denpasar Selatan berjumlah $52 \mathrm{KK}$.

\section{HASIL DAN PEMBAHASAN}

UPTD Puskesmas I Dinas Kesehatan

Kecamatan Denpasar Selatan berlokasi di Kelurahan Sesetan Kecamatan Denpasar Selatan tepatnya di Jalan Gurita No. 8 Denpasar. Adapun batas wilayah kerja UPTD Puskesmas I Dinas Kesehatan Kecamatan Denpasar Selatan mewilayahi 1

\section{Ventilasi}

Tabel 1

Data Hasil Pengukuran Luas Ventilasi Rumah Penderita ISPA Pada Balita Wilayah Kerja UPTD Puskesmas I Dinas Kesehatan Kecamatan Denpasar Selatan

\begin{tabular}{|c|c|c|c|}
\hline No & Ventilasi & Frekuensi & Presentase (\%) \\
\hline 1 & Memenuhi Persyaratan & 24 & 46,2 \\
\hline \multirow[t]{2}{*}{2} & Tidak Memenuhi Persyaratan & 28 & 53,8 \\
\hline & Total & 52 & 100 \\
\hline
\end{tabular}

telah dilakukan pada 52 rumah penderita ISPA pada Balita di Wilayah Kerja UPTD Puskesmas I Dinas Kesehatan Kecamatan Denpasar Selatan didapatkan hasil sebanyak $53,8 \%$ rumah tidak memenuhi persyaratan luas ventilasi alamiah yang permanen.

Sejalan dengan penelitian ${ }^{7}$, Kecamatan Silau Laut Kabupaten Asahan 23 rumah penderita yang memenuhi persyaratan dan 12 rumah penderita yang tidak memenuhi persyaratan. Hal ini disebabkan karena ventilasi atau jendela pada rumah penderita rata-rata tidak dibuka dan masih banyak rumah penderita berbahan mendapatkan hasil bahwa ventilasi rumah 
kaca yang tidak bisa dibuka, sehingga proses pertukaran udara pada rumah tidak lancar.

Berdasarkan Kepetusan Menteri Kesehatan RI No. 829 tahun 1999 tentang kesehatan perumahan menetapkan bahwa luas penghawaan atau ventilasi yang permanen minimal $10 \%$ dari luas lantai ${ }^{2}$.

\section{Lantai ruangan}

Tabel 2

Data Hasil Observasi Lantai Ruangan Rumah Penderita ISPA Pada Balita Wilayah Kerja UPTD Puskesmas I Dinas Kesehatan

Kecamatan Denpasar Selatan

\begin{tabular}{cccc}
\hline No & Lantai Ruangan & Frekuensi & Presentase (\%) \\
\hline 1 & Memenuhi Persyaratan & 52 & 100 \\
2 & Tidak Memenuhi Persyaratan & 0 & 0 \\
\hline & Total & 52 & 100 \\
\hline
\end{tabular}

Berdasarkan hasil observasi yang

telah dilakukan pada 52 rumah penderita ISPA pada Balita di Wilayah Kerja UPTD Puskesmas I Dinas Kesehatan Kecamatan Denpasar Selatan didapatkan hasil bahwa keadaan lantai pada semua rumah telah memenuhi persyaratan dilihat dari keadaan lantai yang sudah kedap air dan mudah dibersihkan.

Sejalan dengan penelitian Riani (2019) hasil penelitian di Desa Mas Kecamatan Ubud Kabupaten Gianyar menunjukkan bahwa hasil penelitian rumah penderita ISPA pada balita memenuhi persyaratan. Hasil penelitian yang didapatkan keadaan sanitasi rumah penderita ISPA pada Balita di Wilayah Kerja UPTD Puskesmas I Dinas Kesehatan Kecamatan Denpasar Selatan sudah memenuhi persyaratan seperti kedap air, tidak lembab, mudah dibersihkan dan semua lantai sudah menggunakan keramik sehingga kejadian ISPA dapat berkurang. 


\section{Kepadatan hunian ruang tidur}

Tabel 3

Data Hasil Wawancara Kepadatan Hunian Rumah Penderita ISPA Pada Balita Wilayah Kerja UPTD Puskesmas I Dinas Kesehatan

Kecamatan Denpasar Selatan

\begin{tabular}{clcc}
\hline No & \multicolumn{1}{c}{ Kepadatan Hunian } & Frekuensi & Presentase (\%) \\
\hline 1 & Memenuhi Persyaratan & 25 & 48,1 \\
2 & Tidak Memenuhi Persyaratan & 27 & 51,9 \\
\hline & Total & 52 & 100 \\
\hline
\end{tabular}

Berdasarkan hasil wawancara yang telah dilakukan pada 52 rumah penderita ISPA pada Balita di Wilayah Kerja UPTD Puskesmas I Dinas Kesehatan Kecamatan Denpasar Selatan didapatkan hasil sebanyak $51,9 \%$ rumah tidak memenuhi syarat kepadatan hunian ruang tidur.

Dalam penelitian Wahyuningsih (2014), menjelaskan bahwa kepadatan hunian rumah akan meningkatkan suhu ruangan yang disebabkan oleh pengeluaran panas badan yang akan meningkatkan kelembaban akibat uap air dari pernapasan tersebut. Dengan demikian semakin banyak penghuni rumah dan semakin cepat udara ruangan mengalami pencemaran gas atau bakteri ${ }^{8}$.

Menurut Keputusan Menteri Kesehatan RI No. 829 Tahun 1999 tetang persyaratan kesehatan perumahan, luas ruangan tidur minimal $8 \mathrm{~m}^{2}$ dengan penghuni tidak lebih dari 2 orang tidur dalam satu kamar, kecuali untuk keluarga yang memiliki anak dibawah umur 5 tahun yang biasanya masih membutuhkan kehadiran orang tuanya ${ }^{2}$. 


\section{Suhu ruangan}

Tabel 4

Data Hasil Pengukuran Suhu Rumah Penderita ISPA Pada Balita Wilayah Kerja UPTD Puskesmas I Dinas Kesehatan Kecamatan Denpasar Selatan

\begin{tabular}{cccc}
\hline No & Suhu & Frekuensi & Presentase (\%) \\
\hline 1 & Memenuhi Persyaratan & 23 & 44,2 \\
2 & Tidak Memenuhi Persyaratan & 29 & 55,8 \\
\hline & Total & 52 & 100 \\
\hline
\end{tabular}

Berdasarkan hasil pengukuran yang telah dilakukan pada 52 rumah penderita ISPA di Wilayah Kerja UPTD Puskesmas I Dinas Kesehatan Kecamatan Denpasar Selatan didapatkan sebanyak 55,8\% rumah tidak memenuhi persyaratan.

Sejalan dengan penelitian Nur dan Janati di Wilayah Kerja Puskesmas Traji Kabupaten Temanggung menunjukkan

\section{Pencahayaan}

Tabel 5

Data Hasil Pengukuran Pencahayaan Rumah Penderita ISPA Pada Balita Wilayah Kerja UPTD Puskesmas I Dinas Kesehatan Kecamatan Denpasar Selatan

\begin{tabular}{cccc}
\hline No & Pencahayaan & Frekuensi & Presentase (\%) \\
\hline 1 & Memenuhi Persyaratan & 24 & 46,2 \\
2 & Tidak Memenuhi Persyaratan & 28 & 53,8 \\
\hline & Total & 52 & 100
\end{tabular}

Berdasarkan hasil pengukuran yang telah dilakukan pada 52 rumah penderita ISPA pada Balita di Wilayah Kerja UPTD Puskesmas I Dinas Kesehatan Kecamatan 
Denpasar Selatan didapatkan hasil sebanyak $53,8 \%$ rumah memiliki pencahayaan ruangan yang tidak memenuhi persyaratan.

Sejalan dengan penelitian Oktaviani (2009), hasil penelitiannya menunjukkan bahwa pencahayaan rumah penderita ISPA pada Balita di Desa Cepogo yang memenuhi persyaratan sebanyak 10 rumah dan yang tidak memenuhi persyaratan sebanyak 27 rumah. Hal ini dapat disebabkan karena jendela kurang luas dan jarang dibuka pada siang hari, tidak memiliki ventilasi. Cahaya matahari penting, karena selain dapat membunuh bakteri-bakteri patogen di dalam rumah juga mengurangi kelembaban ruangan dalam rumah ${ }^{10}$.

Menurut Keputusan Menteri Kesehatan RI No. 829 Tahun 1999 tentang persyaratan kesehatan perumahan, pencahayaan alami dianggap baik jika besarnya minimal 60 lux ${ }^{2}$.

\section{Kelembaban ruangan}

Tabel 6

Data Hasil Pengukuran Kelembaban Rumah Penderita ISPA Pada Balita Wilayah Kerja UPTD Puskesmas I Dinas Kesehatan

Kecamatan Denpasar Selatan

\begin{tabular}{cccc}
\hline No & Kelembaban & Frekuensi & Presentase (\%) \\
\hline 1 & Memenuhi Persyaratan & 22 & 42,3 \\
2 & Tidak Memenuhi Persyaratan & 30 & 57,7 \\
\hline \multicolumn{2}{c}{ Total } & 52 & 100
\end{tabular}

Sejalan dengan penelitian Nur \&

Berdasarkan hasil pengukuran yang telah dilakukan pada 52 rumah penderita ISPA di Wilayah Kerja UPTD Puskesmas I Dinas Kesehatan Kecamatan Denpasar Selatan didapatkan hasil sebanyak $57,7 \%$ rumah memiliki kelembaban ruangan yang tidak memenuhi persyaratan.
Janati (2017), di Wilayah Kerja Puskesmas Traji Kabupaten Tamanggung 6 rumah memenuhi persyaratan dan 21 rumah tidak memenuhi persyaratan. Kelembaban yang 
tinggi dapat menyebabkan membrane mukosa hidung menjadi kering sehingga kurang efektif dalam menghadang mikroorganisme sehingga lebih mudah terkena infeksi saluran pernapasan ${ }^{9}$.

Menurut Keputusan Menteri

Kesehatan RI No. 829 Tahun 1999 tentang persyaratan kesehatan perumahan,

\section{SIMPULAN DAN SARAN}

Berdasarkan hasil penelitian tentang keadaan sanitasi rumah penderita ISPA pada Balita di Wilayah Kerja UPTD Puskesmas I Dinas Kesehatan Kecamatan Denpasar Selatan tahun 2020 dapat disimpulkan:

1. Kondisi ventilasi rumah penderita ISPA pada Balita didapatkan hasil 24 (46,2\%) rumah memenuhi persyaratan dan 28 $(53,8 \%)$ rumah tidak memenuhi persyaratan dikarenakan luas ventilasi alamiah kurang dari 10\% luas lantai dan sebagian dari penderita tidak membuka jendela serta ventilasi ditutup dengan kaca.

2. Kondisi lantai rumah penderita ISPA pada Balita sudah memenuhi persyaratan dimana lantai sudah kedap air dan mudah dibersihkan. kelembaban yang memenuhi persyaratan adalah berkisar antara $40 \%$ sampai dengan 70\%. Kelembaban yang terlalu tinggi dan rendah dapat menyebabkan suburnya pertumbuhan mikroorganisme ${ }^{2}$.
3. Kepadatan hunian ruang tidur pada rumah penderita ISPA bahwa 25 $(48,1 \%)$ rumah memenuhi persyaratan dan 27 (51,9\%) rumah tidak memenuhi persyaratan dimana luas kamar kurang dari $8 \mathrm{~m}^{2}$ dan dihuni lebih dari 2 orang usia diatas 5 tahun.

4. Suhu ruang pada rumah penderita ISPA bahwa $23(44,2 \%)$ rumah memenuhi persyaratan dan $29(55,8 \%)$ rumah tidak memenuhi persyaratan dikarenakan kurangnya ventilasi udara, cuaca panas karena terik matahari yang menyengat pada saat penelitian dan bangunan kamar yang sempit.

5. Pencahayaan pada ruang tidur penderita ISPA pada Balita bahwa 24 (46,2\%) rumah memenuhi persyaratan dan 28 
(53,8\%) rumah tidak memenuhi persyaratan dimana kurangnya pencahayaan karena jendela dan gorden jarang dibuka, ventilasi yang tidak kurang baik sehingga menyebabkan kurangnya cahaya matahari yang masuk kedalam kamar dan kamar menjadi gelap.

6. Kelembaban ruangan pada rumah penderita ISPA Balita bahwa 22 $(42,3 \%)$ rumah memenuhi persyaratan dan $30(57,7 \%)$ rumah tidak memenuhi persyaratan dimana masyarakat jarang membuka jendela dan kamar tidur yang tidak rapi masih banyak tumpukan baju. Berdasarkan hasil penelitian yang telah dilakukan maka saran yang dapat disampaikan penulis adalah :

1. Bagi masyarakat penderita penyakit ISPA diharapkan menerapkan hidup bersih dan sehat dalam kehidupan sehari-hari dengan membersihkan dan merapikan tempat tidur secara rutin untuk mencegah terjadinya penyakit ISPA dan untuk menanggulangi suhu dan kelembaban yang tidak memenuhi syarat yaitu masyarakat dapat membuka jendela setiap hari dan menambah pencahayaan buatan untuk pencahayaan yang tidak memenuhi persyaratan.

2. Bagi Puskesmas

Kepada petugas khususnya UPTD Puskesmas I Dinas Kesehatan Kecamatan Denpasar Selatan sebaiknya lebih meningkatkan kerja sama dengan perangkat desa untuk meningkatkan penyehatan perumahan pada desa tersebut.

3. Bagi peneliti selanjutnya

Diharapkan agar melakukan penelitian dengan jumlah populasi atau sampel yang lebih besar dan dengan variabel yang mempengaruhi keadaan sanitasi rumah penderita ISPA.

\section{DAFTAR PUSTAKA}

1. RI, D. Informasi Tentang ISPA Pada Balita dan Pusat Penyuluhan Kesehatan Masyarakat. (2013).
2. RI, K. 3. Keputusan Menteri Kesehatan RI No. 829/Menkes/SK/VII/1999 tentang Persyaratan Kesehatan Perumahan. 
(1999).

3. Jayanti. Pengaruh Lingkungan Rumah Terhadap ISPA Balita di Wilayah Kerja Puskesmas Tanjung Haloban Kabupaten Labuhan Batu Tahun 2017. (2018).

4. WHO. Tatalalaksana Penyakit Infeksi Saluran Pernafasan Akut Pada Anak. (2013).

5. Bali, D. P. Profil Kesehatan Provinsi Bali 2017. (2017).

6. Notoatmodjo, S. Metodelogi Penelitian Kesehatan. (Rineka Cipta, 2012).

7. Ira Lubis, F. Hubungan Kondisi Fisik Rumah dan Keberadaan Perokok dalam Rumah dengan Kejadian ISPA pada Balita di Desa Silo Bonto, Kecamatan Silau Laut, Kabupaten Asahan. J. Ilm.
Kesehat. Masy. 11, 166-173 (2019).

8. Wahyuningsih, S., Raodhah, S., Basri, S. \& Kunci, K. Infeksi Saluran Pernafasan Akut ( ISPA ) pada Balita di Wilayah Pesisir Desa Kore Kecamatan Sanggar Kabupaten Bima. (2014).

9. Janati, J. N. A. \& Siwiendrayanti, A. Kebiasaan Orang Tua Dengan Kejadian Ispa Pada Balita Di Wilayah Kerja Puskesmas Traji Kabupaten Temanggung. J. Kesehat. Pena Med. 7, 1-13 (2017).

10.Oktaviani. Hubungan Antara Sanitasi Fisik Rumah Dengan Kejadian Infeksi Saluran Pernapasan Atas (ISPA) Pada Balita di Desa Cepogo Kecamatan Cepogo Kabupaten Boyolali. (2009). 